\title{
The choice of control points of projects taking into account possible change of structure of works
}

\author{
Maxim A. Maron \\ Postgraduate Student, Department of Business Analytics, Doctoral School of Computer Science \\ National Research University Higher School of Economics \\ Address: 20, Myasnitskaya Street, Moscow, 101000, Russian Federation \\ E-mail: maxim.tbconsulting@gmail.com
}

\begin{abstract}
This article is devoted to a problem of controlling implementation of multiscenario projects when it is necessary to provide not one, but several scenarios of performance differing from each other in structure of works. As a control method, we propose carrying out intermediate checks. The task is to determine after which works you have to carry out the checks. A heuristic method of the solution of this task is offered on the basis of an information approach. The places of performance of checks (control points) are defined step by step. Each check is chosen so that it gives maximum information (according to Shannon) concerning the work from those already completed that has been performed incorrectly. In calculations, we consider not only previously established control points, but also probabilities of implementation of various scenarios of implementation of the project under examination.

The solution for two very important practical cases is proposed: when the number of admissible intermediate checks is set and when their number is not set but achievement of a certain level of information completeness of control is required. In practice, the number of intermediate checks is limited from above by the budget for costs of control which is selected by the sponsor of the project. Information completeness of the diagnosis, in turn, is inversely proportional to the risk that the wrong implementation of the project will be revealed only after it ends. In this regard, the project manager demands that information completeness of control be no lower than a certain level.

The results received are sought, first of all, by heads of design offices of large construction companies realizing standard projects in various natural and climatic conditions (in their practice practically all projects are multiscenario). Results can also be requested in the practice of the Ministry of Emergency Situations.
\end{abstract}

Key words: complex project, control points, checks, informational completeness.

Citation: Maron M.A. (2016) The choice of control points of projects taking into account possible change of structure of works. Business Informatics, no. 2 (36), pp. 57-62. DOI: 10.17323/1998-0663.2016.2.57.62.

\section{Introduction}

$\mathrm{T}$ The main feature of many projects is uniqueness of the structure of works. At the same time, a project plan is created in advance. For exact implementation of the project plan and to reduce the probability of making a mistake, intermediate inspections (checks) of results of performance of work are carried out. This type of control differs from internal checks of works. Along with the high cost and considerable duration, such control allows us to get the best idea of the correctness of implementation of the project. Furthermore, such checks cover not only concrete work, but also works which logically preceded the one being checked. Considering their characteristics, inspections of this kind can seldom be carried out after each work. There are methods of arranging control points in the 
project according to the available plan; however, they are inapplicable in cases when the plan changes during implementation of the project.

One of the possible solutions is to try to foresee possible changes of structure of works. In this case, for some possible situations different scenarios of project implementation are created. This line is characteristic of projects having a possibility of serious change in the structure of works depending on the situation arising during implementation of the project. The standard mathematical model of the project is a directed graph whose tops correspond to works, and arches - to logical links between them. This model does not provide scenarios, but they are necessary to consider when planning the project's possible changes of structure of works at the stage of its realization. The GERT analysis (Graphical Evaluation and Review Technique) $[1-3]$ is devoted to these questions.

Research shows that modern methods of analysis, including GERT, do not touch on the issue of arrangement of control points in multiscenario projects. Because of this, in projects with already allocated resources for carrying out checks with certain places of arrangement, you have to spend additional resources - for re-planning and carrying out other checks on the change in the structure of works.

The research objective is to create a method of arranging control points applicable to multiscenario projects. For this purpose, it is necessary to create a method of arranging control points in a situation when it is necessary to maximize information completeness of control at a set number of control points and when you must define the minimum set of control points providing the required information completeness of control.

\section{Theoretical bases for defining control points in projects}

Work [4] offers an approach to the choice of the set number of control points of the project based on calculation of entropy of the result of checking according to Shannon. Points are chosen one after another. On each step of the choice from the graph of the project you de- lete the subgraphs consisting of the tops corresponding to those works whose results influence the result of earlier checked work. The number of points of control is considered initially set, (for example, for economic reasons) and unchangeable. The possibility of a change in the structure of the works is not considered. With these restrictions, an arrangement of control points whereby minimal time is spent searching for incorrectly performed work is considered optimum. On the basis of imitation modeling, it has been established that the heuristic approach offered in work [4] yields results close to optimum.

If there is a need to consider possible changes of structure of works of the project, then the method offered in work [4] is inapplicable. At the same time, as will be shown below, it is necessary not only to reject the assumption of an invariable quantity of control points, but also to change the criterion of optimality. However, in this case it is possible to apply ideas of the information approach.

\section{Formal delivery of a problem of formation of control points}

Let's consider a standard project about which it is known that it can pass in concrete realization according to various scenarios $\{1,2, \ldots, r\}$. Each scenario $j$ can put in compliance the plan displayed by the graph of $G$ whose tops correspond to works, and arches - to logical links between them, the "finish to start" type. Let's further call such a model the scenario graph. The scenario $j$ can be realized with probability of $p_{j}$. Scenario graphs have common tops. For simplicity, we will consider that there is one general output top. The work corresponding to it is carried out under any scenario and is the final planned work of the project. Works and the tops corresponding to them are numbered, so that each work gets a number once even if it enters several scenario graphs. In total, there is $n$ of works (tops).

An example is given in figure 1 , where scenarios are possible with probabilities, $p_{1}=0,8$ and $p_{2}=0,2$ to which there correspond the graphs $G_{1}=\{1 ; 2 ; 3 ; 4 ; 5\}$ and $G_{2}=\{1 ; 2 ; 6 ; 7 ; 4 ; 5\}$.

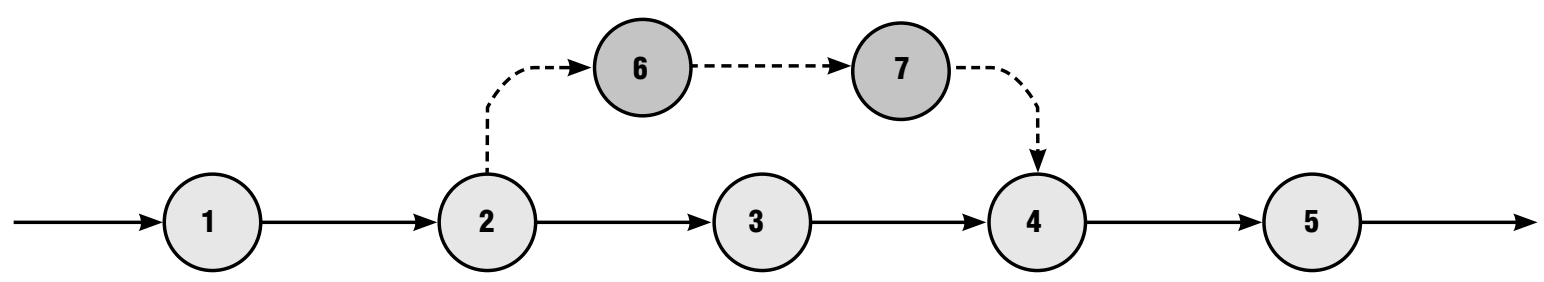

Fig. 1. Example of scenario graphs 
After finishing the work, a final inspection of compliance of the result of the project with the established requirements is always carried out. If its result is negative, then we begin the search for the work which was executed incorrectly. At the same time, it is already precisely known according to what scenario the project passed. Accordingly, the scenario graph is unambiguously defined and it is known among what works it is necessary to look to find what was incorrectly executed.

There is an opportunity to plan no more than $m<n$ intermediate checks - control points. A check on the work corresponding to the top of $i$, yields a negative result if this work is performed incorrectly or if at least one of the previously performed works to which the tops from which the top of $i$ is achievable was incorrectly executed. Let's consider further the setting of a task for two cases: in the conditions of initial and residual entropy. Moreover, we shall consider the information entropy estimated on Shannon's formula [5].

The task: to construct an optimum set of control points of the project.

\subsection{Determination of initial information entropy of a multiscenario project}

Before implementing the project, we do not know according to which scenario it is necessary to realize it. Accordingly, any of $\mathrm{n}$ of the works which are part of it can be executed incorrectly. Let's consider the project as the object of a diagnosis [6]. Let's enter a random variable of $N$ - the number of the work which can be executed wrongly; the area of its possible values $-\{1,2, \ldots, n\}$. At the same time, when the project is complete, it is already precisely known according to what scenario $j$ it was realized. If the finishing check yielded a negative result, then only those works to which there correspond $i$ tops belonging in the graph $G_{j}$ could be performed incorrectly. Accordingly, provided that the realized scenario $j$ is known, entropy of a random variable of $N$ is defined by the expression:

$$
H\left(N \mid G_{j}\right)=-\sum_{i \in G_{j}}\left(p_{i j} \cdot \log _{2} p_{i j}\right),
$$

where $p_{i j}$ - probability that work of $i$ is incorrectly performed in case implementation of the project took place according to the scenario $j$ and the finishing check yielded negative result.

Since at the planning stage it is only possible to assume with probability of $p_{j}$ that the scenario $j$ will be realized, the initial entropy of $H(N \mid J)$ a random variable of $N$ is the mean value for $H\left(N \mid G_{j}\right)$ and also is defined by expression

$$
H(N \mid J)=\sum_{j=1}^{r} p_{j} \cdot H\left(N \mid G_{j}\right) .
$$

Let's assume that in our example all works are identical in terms of the possibility of making a mistake. Then at the first scenario $(j=1)$ for all $i$ we have $p_{i 1}=1 / 5$. In the second scenario $(j=2)$ for all $i$ we have $p_{i 2}=1 / 6$. As a result, we get:

$$
H(N \mid J)=0,8 ц \log _{2} 5+0,2 \cdot \log _{2} 6=2,37 \text { bit. }
$$

\subsection{Determination of an optimum set of control points in conditions of residual information entropy}

Control points are established for the purpose of revealing in a timely manner incorrectly performed work or, at least, reducing uncertainty concerning what work is performed incorrectly if the finishing check yields a negative result. The last will allow us to reduce time searching for incorrectly performed work.

Let's denote the planned set of $m$ of control points through $K_{m}$. The number of various possible sets is equal in our case to the number of combinations from $(n-1)$ on $\mathrm{m}$. To each of them there corresponds the residual entropy of a random variable of $N$. Let's denote this value as $\left.H(N \mid J) \mid K_{m}\right)$. Calculation of this value on the basis of the general determination of entropy according to Shannon demands performance of a large number of bulky calculations. At the same time, the author found a rather easy way of her calculation: it is generalization of the method offered in work [7].

To the concrete option of arrangement of the $K_{m}$ control points at each of possible scenarios $j$ there corresponds a multitude of works whose wrong performance this set cannot define accurately before the concrete work. Let's designate this set through $F_{j}$. Only these works create residual uncertainty.

For example, $K_{2}$ set $=\{2 ; 4\}$ under the scenario $j=1$ to which there corresponds graph $G_{1}=\{1 ; 2 ; 3 ; 4 ; 5\}$ defines unambiguously only the wrong performance of work to which there corresponds the top 5 . Therefore, $F_{1}=\{1 ; 2 ; 3 ; 4\}$

The large set $F_{j}$ consists of subsets of works the accuracy of which the $K_{m}$ set defines as incorrectly executed. In other words,

$$
F_{j}=\bigcup f_{l j} .
$$

So, in the case under consideration

$$
F_{1}=\{1 ; 2\} \bigcup\{3 ; 4\} \text {. }
$$


It is possible to show that

$$
\begin{gathered}
\left.H\left[(N \mid J) \mid K_{m}\right)\right]=\sum_{j=1}^{r} p_{j} \times\left\{\sum _ { f _ { l j } \in F _ { j } } \left[\left(\sum_{i \in f_{i j}} p_{i j}\right) \times\right.\right. \\
\left.\left.\times \log _{2}\left(\sum_{i \in f_{i j}} p_{i j}\right)\right]-\sum_{i \in F_{j}} p_{i j} \log _{2} p_{i j}\right\} .
\end{gathered}
$$

Let's carry out on a formula (4) the calculation of residual entropy for our example.

The large set $F_{1}$ is defined above. The set of $F_{2}$ has an appearance

$$
F_{2}=\{1 ; 2\} \bigcup\{6 ; 7 ; 4\} .
$$

Applying the formula (4), we obtain:

$$
\begin{gathered}
\left.H\left[(N \mid J) \mid K_{2}\right)\right]=0,8 \cdot\left[(4 / 5) \cdot \log _{2}(2 / 5)-(4 / 5) \cdot \log _{2}(1 / 5)\right]+ \\
+0,2 \cdot\left[(2 / 6) \cdot \log _{2}(2 / 6)+(3 / 6) \cdot \log _{2}(3 / 6)-\right. \\
-(5 / 6) \cdot \log _{2}(1 / 6)=1,03 \text { bit. }
\end{gathered}
$$

\subsection{Maximizing information completeness of controls}

As a measure to reduce the uncertainty corresponding to a set of the $K_{m}$ control points, we propose to reduce entropy of the random variable $N$ with respect to the initial value expressed as a percentage

$$
W=\frac{H(N \mid J)-H\left[(N \mid J) \mid K_{m}\right]}{H(N \mid J)} 100 \% .
$$

Let's call this size the information completeness of control (ICC).

For the example being reviewed

$$
W=(2,37-1,03) / 2,37) \cdot 100 \%=57 \% .
$$

Information completeness of control (ICC) is maximum with minimal residual entropy. However, it is precisely ICC which is intuitively a clear measure of quality of the intermediate control of works which the curator of the project can set as the initial requirement.

\section{Modeling the distribution of control points}

Now, when the problem defining the optimum arrangement of the set number of control points executed earlier is specified by defining the criterion of optimality, it is possible to offer a method for finding the solution.

The method consists of the following steps.

1. On the first step, we will determine the check $i_{1}$ to which there corresponds the minimum value of residual entropy of $\left.H\left[(N \mid J) \mid K_{1}\right)\right]$. At the same time, we use a formula (4).
2. We also find the second check $i_{2}$ from the principle of a minimum of residual entropy provided that $i_{1}$ enters a required set.

3. We continue adding to the set taking into account the checks which are earlier included in $i_{t}$ up to $m$ control points is established.

With such an heuristic approach to searching for possible combinations $C_{n-1}^{m}$ is replaced with consecutive consideration $(n-1) ;(n-2) ; \ldots ;(n-m)$ of options of arrangement. In total for $\mathrm{m}$ of steps it is necessary to compare

$$
S=m \frac{(2 n-m-1)}{2} .
$$

options. So, at $n=100$ and $m=10$ it is necessary to compare $S=945$ options, each of which assumes performance of calculations for a formula (4). At the same time, full search would demand comparison of $1,73 \cdot 10^{13}$ options of arrangement of control points.

One must pay attention when implementing the project that it is not necessary for each of $m$ planned checks be executed, since some of them can correspond to the works performed under scenarios which will not arise under this concrete implementation of the project.

Presently the author is developing a program complex for realizing the method proposed. One of the main elements of component checking efficiency of the heuristic approach is based on ideas of modeling implementation of the project $[8,9]$. As alternatives in terms of efficiency, search methods on graphs [10] are being considered.

If the curator of the project sets the required ICC, then under the conditions formulated in section 2, the problem of arranging control can be formulated as follows: to establish the minimum numbery of control points so that the ICC reached was not less than required.

The problem can be solved by a method similar to the one offered above, with the difference that addition of a set continues until the required ICC is reached or exceeded.

\section{Conclusion}

In this article the following new results are set out:

1. We introduced the concept of information completeness of control of the project, realization of which makes several scenarios possible.

2. We have proposed methods of choosing the points of control in multiscenario projects for two cases:

when it is necessary to maximize information completeness of control with a given number of control points; 
when it is required to define the minimum set of control points providing the required information completeness of control.

The results obtained will be in demand, first of all, among heads of design offices of large construction companies realizing standard projects in various natural and climatic conditions. In their practice practically all projects [11] are multiscenario. Such results can also be of use the practice of the Ministry of Emergency Situations.

A program complex compatible with the main CASE control facilities projects which observe the principles of the Project Management Body of Knowledge (PMBoK) is being developed for realization of the methods offered by the author. The basis of a complex is provided by methods of imitation modeling for the implementation of multiscenario projects.

\section{References}

1. Pritsker A.A.B., Happ W.W. (1966) GERT: Graphical Evaluation and Review Technique. Part 1. Fundamentals. Journal of Industrial Engineering, vol. 17, no. 5. pp. 267-274.

2. Pritsker A.A.B., Whitehouse G.E. (1966) GERT: Graphical Evaluation and Review Technique. Part 2. Applications. Journal of Industrial Engineering, vol. 17, no. 5, pp. 293-301.

3. Pritsker A.A.B. (1974) The precedence GERT user's manual. Lafayete, IN: Pritsker \& Associates.

4. Maron A.I., Maron M.A. (2012) Informatsionnyy podkhod k organizatsii kontrolya proektov [Information approach for project's checking]. Business Informatics, no. 4 (22), pp. 54-60 (in Russian).

5. Dukhin A.A. (2007) Teoriya informatsii [Theory of information]. Moscow: Helios ARV (in Russian)

6. Malkin V.S. (2008) Tekhnicheskaya diagnostika [Technical diagnostics]. Saint Petersburg: Lan (in Russian).

7. Maron A.I., Maron M.A. (2010) Optimizatsiya kontrolya v programmnykh proektakh razrabotki bol'shikh sistem [Control optimization in big systems development projects]. Proceedings of International conference "Information technologies in science, education, telecommunications and business". Crimea, Yalta - Gurzuf, 20-30 May 2010, pp. 46-48 (in Russian).

8. Akopov A.S. (2014) Imitatsionnoe modelirovanie [Simulation modeling]. Moscow: Urait (in Russian).

9. Isaev D.V. (2014) Modelirovanie realizatsii proektov vnedreniya analiticheskikh informatsionnykh sistem [Modeling of analytical information systems implementation projects]. Audit and Financial Analysis, no. 6, pp. 416-422 (in Russian).

10. Aleskerov F.T., Khabina E.L., Shvarts D.A. (2012) Binarnye otnosheniya, grafy i kollektivnye resheniya [Binary relations, graphs and group decisions]. Moscow: Fizmatlit (in Russian).

11. Tsipes G.L., Tovb A.S. (2009) Proekty i upravlenie proektami v sovremennykh kompaniyakh [Projects and project management in modern companies]. Moscow: Olymp-Business (in Russian).

\section{Выбор контрольных точек проектов с учетом возможного изменения состава работ}

\section{M.A. Марон}

аспирант кафедры бизнес-аналитики, аспирантская школа по компьютерным наукам

Национальный исследовательский университет «Высшая школа экономики»

Адрес: 101000, г. Москва, ул. Мясницкая, д. 20

E-mail: maxim.tbconsulting@gmail.com

\section{Аннотация}

Статья посвящена проблеме контроля реализации мультисценарных проектов, при планировании которых необходимо предусмотреть не один, а несколько сценариев выполнения, отличающихся друг от друга составом работ. В качестве метода контроля предлагается проведение промежуточных проверок. Задача состоит в том, чтобы определить после выполнения каких работ эти проверки необходимо осуществлять. Предложен эвристический метод решения данной задачи на основании информационного подхода. Он состоит в том, что места выполнения проверок (контрольные точки) определяются последовательно. Каждая проверка выбирается так, чтобы она давала максимум информации (по Шеннону) относительно того, какая работа из уже завершенных выполнена неправильно. В расчетах учитываются не только ранее установленные контрольные точки, но и вероятности реализации различных сценариев выполнения диагностируемого проекта.

Предложено решение для двух наиболее важных практических случаев: когда число допустимых промежуточных проверок задано, и когда их число не задается, но требуется достижение определенного уровня информационной полноты контроля. На практике число промежуточных проверок ограничивается 
сверху бюджетом затрат на контроль, который выделяет спонсор проекта. Информационная полнота диагноза, в свою очередь, обратно пропорциональна риску того, что неправильное выполнение проекта будет обнаружено только по его завершении. В связи с этим руководитель проекта требует, чтобы информационная полнота контроля была не меньше определенного уровня.

Полученные результаты востребованы в первую очередь руководителями проектных офисов крупных строительных компаний, реализующих типовые проекты в различных природных и климатических условиях (в их практике мультисценарными являются практически все проекты). Результаты также могут быть востребованы в практике Министерства по чрезвычайным ситуациям (МЧС).

Ключевые слова: сложный проект, контрольные точки, проверки, информационная полнота.

Цитирование: Maron M.A. The choice of control points of projects taking into account possible change of structure of works // Business Informatics. 2016. No. 2 (36). P. 57-62. DOI: 10.17323/1998-0663.2016.2.57.62.

\section{Литература}

1. Pritsker A.A.B., Happ W.W. GERT: Graphical Evaluation and Review Technique. Part 1. Fundamentals // Journal of Industrial Engineering. 1966. Vol. 17. No. 5. P. 267-274.

2. Pritsker A.A.B., Whitehouse G.E. GERT: Graphical Evaluation and Review Technique. Part 2. Applications // Journal of Industrial Engineering. 1966. Vol. 17. No. 5. P. 293-301.

3. Pritsker A.A.B. The precedence GERT user's manual. Lafayete, IN: Pritsker \& Associates, 1974

4. Марон А.И., Марон М.А. Информационный подход к организации контроля проектов // Бизнес-информатика. 2012 . № 4 (22). С. 54-60.

5. Духин А.А. Теория информации. М.: Гелиос АРВ, 2007. 248 с.

6. Малкин В.С. Техническая диагностика. СПб: Лань, 2008. 272 с.

7. Марон А.И., Марон М.А. Оптимизация контроля в программных проектах разработки больших систем // Труды международной конференции «Информационные технологии в науке, образовании, телекоммуникации и бизнесе», Крым, Ялта - Гурзуф, 2030 мая 2010 г. С. $46-48$.

8. Акопов А.С. Имитационное моделирование. М.: Юрайт, 2014. 389 с.

9. Исаев Д.В. Моделирование реализации проектов внедрения аналитических информационных систем // Аудит и финансовый анализ. 2014. № 6. С. 416-422.

10. Алескеров Ф.Т., Хабина Э.Л., Шварц Д.А. Бинарные отношения, графы и коллективные решения. 2-е изд. М.: Физматлит, 2012. $342 \mathrm{c}$.

11. Ципес Г.Л., Товб А.С. Проекты и управление проектами в современных компаниях. М.: Олимп-Бизнес, 2009. 480 с. 